\title{
Higher Education Transformations for Global Competitiveness: Policy Responses, Social Consequences and Impact on the Academic Profession in Asia
}

\author{
Ka Ho Mok \\ Department of Asian and Policy Studies, The Hong Kong Institute of Education, 10 Lo Ping Road Tai Po, \\ N.T., Hong Kong, Hong Kong SAR.
}

Since the mid-1990s, the pressure of globalization and the pressing demands of a knowledge economy led to a series of educational reforms. The focus of these was the promotion of quality education and massification of higher education. After the Asian financial crisis in 1997, the governments in different parts of Asia have implemented comprehensive reforms to their higher education systems in order to enhance their global competiveness. Confronted with increasing pressure for global university ranking, governments and universities in Asia have tried to adopt different strategies in terms of special funding schemes, and different forms of measures in shaping teaching, learning and research activities to enhance their global ranking. This article sets out against the context briefly outlined above to highlight major higher education transformations for global competitiveness, with particular reference to discuss policy responses, social consequences, and impact on the academic profession in Asia especially when major attention is geared towards the quest for global university ranking among universities in Asia.

Higher Education Policy (2015) 28, 1-15. doi:10.1057/hep.2014.27

Keywords: managing global cities; massification of higher education; labour market; regional education hub; entrepreneurial university

\section{Introduction}

This special issue has chosen a few papers presented at the international conference entitled 'Managing Global Cities: Enhancing Hub Status and Implications for Education and Development', which was successfully held at the Hong Kong Institute of Education in February 2014, and the 10th Annual Conference of East Asia Social Policy Research Network held in Beijing in July 2013. These papers address different aspects of human capital management, particularly how different East Asian economies have reformed their higher education systems to achieve excellence and maintain global competitiveness. Researchers and scholars who presented at these conferences debated on issues related to the growing challenges of urbanization in East Asia, especially the effects of the massification and 
privatization of higher education in the region. This special issue aims to examine how higher education systems have been transformed in Asia to enhance their global competitiveness, especially to discuss the major policies or strategies adopted by Asian governments in general and higher education institutions in particular to meet the pressing demand for higher education, seeking global ranking and asserting their regional and global influences. This introductory article critically discusses major social consequences and the impact on the academic profession in Asian higher education systems experiencing rapid transformations.

\section{Success in Higher Education in East Asia: Issues and Challenges}

The development of higher education in most countries in Asia is a remarkable success story. Higher education across the region enjoys a high level of government support. Government leaders understand that higher education is an important ingredient in the economic and social development of their country. They recognize that the globalization of markets, the interdependency of international financial systems, the expanded role of technology, and high speed communications have created an enormous need for highly skilled technical, professional, and managerial leaders. In addition, government leaders also understand that primary and secondary school graduates are unable to manage modern economies (Shaw et al., 2011). Enrolment has grown and participation in higher education has diversified. New universities have been created, and universities are experimenting with new forms of instructional delivery. Nonetheless, the rapid expansion of higher education, especially the significant increase in higher education enrolment, has inevitably challenged conventional higher education governance and management, graduate employment, and competitiveness of individual institutions in the highly competitive global market. The present issue sets out against this wider context to examine recent transformations taken place in Asian higher education systems, discussing the impacts and social consequences of these changes.

State sources of funding and support will never meet the pressing demands from students and parents in Asia for high quality education. Therefore, Asian governments have adopted policies to encourage the private sector to be involved in developing an education market and public universities to engage with the industry and business for more and stronger cooperation. States want to see improved synergy between the university and enterprise for promoting innovation, knowledge transfer, and different kinds of entrepreneurial activities (Mok, 2013a; Chan and Mok, 2014). Through a comparative study related to university-enterprise cooperation in selected East Asian economies, such as Singapore, Taiwan, South Korea, and Hong Kong, Mok (2013a) clearly showed a growing regional trend in Asia to foster stronger and closer relationships between the university sector and industry and business. The development of these relationships has not only diversified economic activities that 
provided strong impetus to the development of new economic pillars in South Korea and Singapore, with innovation and creativity being integrated and promoted as new industries, but has also affected the way universities are managed and how performance is measured (Mok, 2012). Mok (in this issue; see also Mok, 2013b; Mok and Nelson, 2013) conducted surveys and field interviews to examine how academics assess and evaluate the call for deeper university-enterprise cooperation in East Asia. Mok revealed diverse views and opinions of faculty members from different academic disciplines, with engineering and business groups showing more support, whereas humanities and social sciences colleagues have criticized higher education being run as commercial companies, with education ideals being jeopardized. The call for a closer relationship among university, industry, and business has no doubt made academics more critical against the imposed forms of privatization, marketization, and commercialization of higher education (Turner and Yolcu, 2014). We have seen success in higher education developments in Asia, but we have also observed certain issues and challenges. This special issue has identified a few major policy and governance issues faced by higher education in Asia, particularly when Asian governments have intended to increase higher education enrolments by massifying their systems.

\section{Massification of Higher Education and Labour Market}

Calderon (2012) reported that enrolment in higher education in Asia has increased by over $50 \%$ in the last decade and by a higher percentage in various specific countries of Asia.. However, the rapid expansion of higher education in the last decade has led to issues regarding academic standards and quality of universities in mainland China, Taiwan, South Korea, and Japan (Mok, 2013a). Well aware of the importance of increasing higher education opportunities to prepare their citizens for the knowledgebased economy, the Taiwan government allowed the higher education sector on the island state to upgrade a number of colleges focusing on technology. Such an expansion has inevitably resulted in more supply than demand mainly because Taiwan is one of the countries with the lowest birth rate in the world. The significant demographic change and massification of higher education in Taiwan have caused heated debates on the ways in which quality in higher education can be ensured, as well as how the labour market can provide sufficient employment opportunities for university graduates (Mok et al., 2013).

In this issue, Sheng-Ju and Liang-Wen critically review how the higher education system has massified in Taiwan since the 1990s. They report that Taiwanese higher education has evolved from an elite system to a universal one in the past two decades because of such imperatives. The rapid expansion of higher education is also characterized by salient features, such as the pursuit of higher degrees, an enlarged private sector, and diminishing numbers of junior college institutions or students. 
The authors explore whether these macro changes at the national level have brought challenges to the labour market. The findings clearly reveal that increased participation has eased the pressure of access to higher education in Taiwan. However, intensified competition for employment has incurred extra monetary cost and uncertain wage prospects at the individual level because of the increased number of graduates. Moreover, disadvantaged students might suffer the most in terms of financial investment in and rate of return to higher education because of this massification.

The problem faced by young university graduates is the most socially and politically significant issue related to the massification of higher education in Taiwan. Young university graduates must often decide whether to take up relatively low-pay and low-skill jobs available in the labour market. However, most of these graduates prefer to be employed in professions with a high social or professional status, but such jobs are not sufficiently created when the global and regional market economy became insufficiently dynamic after the 2008 global financial crisis. Comparing their present salary with that of their cohorts 10 years ago, many young graduates complain about the stagnation of salaries in Taiwan. Therefore, most of these university graduates openly declare their anxiety and feelings being under-valued in the labour market vividly shown with their unpromising futures in the job market. $\mathrm{Ku}$ (2014) pointed out that the dissatisfaction of students with the economic future has accumulated into anti-establishment attitudes and also in an anti-government movement in Taiwan. During the Sunflower Social Movement in March 2014, several university students staged their dissatisfaction with the bill, passed by the ruling party, for fostering more economic cooperation between Taiwan and mainland China. $\mathrm{Ku}$ (2014) provided a social and political analysis for the movement and argued that Taiwan has democracy without governance. Ku further explained why policy implementation against the aforementioned particular social, political, and economic contexts has failed in Taiwan.

Similar to Taiwan, mainland China has massified its higher education system. According to the Education Blueprint 2020 (also known as Outline for Medium and Long-Term Education Development), the Chinese government is keen to increase higher education enrolment from the present $24-40 \%$ of the relevant age cohorts of high school graduates. In line with this policy, higher education institutions in China have experienced a significant increase in student population. The increase in higher education enrolment began when the former Party Leader Jiang Zimen called for producing world-class universities in China in the early 1990s. Subsequently, the higher education sector in China has experienced significant increases in university students not only in the mainland but also outside the country by sending students overseas. Privatizing and marketing higher education along the neo-liberal approach, the higher education sector has expanded significantly in the last few decades but experienced negative social and economic consequences when higher education is run as a business (Carnoy et al., 2013). Wang and Mok (2014) critically reviewed how higher education in China has been massified through neo-liberal ideas and 
practices. They found that the efficiency gained by running higher education through market-driven strategies has inevitably compromised education quality and equality. Similarly, Zha and Lin (2014) offer an interesting analysis on how China has massified higher education by policy execution, whereas Wolverton (2014) outlines how China and the United States have made serious attempts to produce more dynamic creators by increasing the number of higher learning opportunities. With these research findings, the importance of increasing the number of higher education opportunities for young generations cannot be doubted. However, we should be aware that the massive expansion of higher education unquestionably creates pressure on the employment of graduates.

Wing Kit Chan — in this special issue - argues that the number of Chinese citizens unsure of their prospects after graduation has reached an unprecedented level of 2 million since the summer of 2013. This group of graduates is not entitled to claim any benefits from social insurance schemes based on formal employment. In addition, if they are away from home, they do not have any access to other supplementary benefits of the social protection system based on household registration status, which is financed and provided by the local governments of host cities. The Chinese government has introduced a range of policy measures in the past years with an emphasis on 'flexible employment', which is an umbrella term for several types of atypical jobs. Nonetheless, we have observed the growing anxiety commonly shared by university graduates in mainland China because over 7 million university graduates are produced annually. The employment rates among graduates released by government agencies or research institutes are also derived in a fashion that even part-time jobs are considered. Wing Kit Chan's contribution critically reviews the development of graduate employment policy with an emphasis on recent changes against the background of massive unemployment among graduates. The article calls for a thorough reform on the higher education system in China by evaluating the effectiveness of new policy measures.

In view of the above research findings, the role of education in upward social mobility is therefore questioned. Education may contribute to increased earnings and possibility for the upper social class in a less globalized and elite higher education system. However, the status quo has changed, particularly against ever-intensifying globalization and massification of higher education. Specifically, a degree does not assure employment, high earnings, and upward social mobility. The promotion of social mobility through university credentials has become challenging in both developed and emerging economies. Haveman and Smeeding (2006) showed the growing income-related gap both in access to and in success in higher education in America. In top-tier colleges and universities, almost three-quarters of the entering class is from the highest socioeconomic quartile. The pool of qualified youth is far greater than the number admitted and enroled. China shares similarities with the United States. A research team from Peking University (Wen, 2005) has found that 
if. Ka Ho Mok

6

Higher Education Transformations for Global Competitiveness

Table 1 Graduate employment in China (in percentage)

\begin{tabular}{lrrrrr}
\hline & 2003 & 2005 & 2007 & 2009 & 2011 \\
\hline With employment contract & 40.7 & 47.2 & 40.4 & 34.5 & 43.3 \\
Continue to further study (domestic) & 15.1 & 16.8 & 14.1 & 18.3 & 13.7 \\
Leave mainland China & & 2.3 & 2.7 & 3.2 & 2.6 \\
Freelance & 4.0 & 3.6 & 4.1 & 3.3 & 4.3 \\
Self-employed & & & 3.2 & 2.4 & 3.2 \\
Other types of flexible employment & & & 6.6 & 5.4 & 5.1 \\
Job seeking & 35.8 & 22.4 & 22.6 & 26.4 & 21.9 \\
Preparing for further study without a job & 1.7 & 4.8 & 2.9 & 3.1 & 2.4 \\
Other types of being jobless & & & 2.4 & 2.2 & 2.1 \\
Others & 2.7 & 3.0 & 1.1 & 1.2 & 1.5 \\
\hline
\end{tabular}

Source: Yue $(2012,35)$.

Table 2 Starting salary per month of schooling levels (RMB)

\begin{tabular}{lcccccc}
\hline & 2003 & 2005 & 2007 & 2009 & 2011 & Increase rate per year $(\%)$ \\
\hline 2-/3-year college & 1,356 & 1,413 & 1,410 & 1,510 & 1,856 & 4 \\
Bachelor & 1,502 & 1,618 & 1,788 & 2,276 & 2,743 & 7.8 \\
Master & 3,009 & 2,790 & 3,469 & 3,637 & 4,003 & 3.6 \\
Ph.D. & 3,021 & 3,035 & 3,252 & 3,757 & 5,118 & 6.8 \\
Total & 1,569 & 1,659 & 1,798 & 2,331 & 2,394 & 5.4 \\
\hline
\end{tabular}

Source: Yue $(2012,38)$.

students with good family background account for a large proportion of enrolments in top-tier universities in China. Higher education might bring good job opportunities and high earnings, based on human capital theory. However, family background is more important than higher education in enhancing upward social mobility for youth in the ever-intensifying globalized and expanding higher education settings (Coleman et al., 1966; Wen, 2005).

Yue (2012) claimed that longitudinal studies on graduate employment rate have accounted for roughly $70 \%$ of studies on this topic since the dramatic expansion except in 2003 (see Table 1). In addition, the starting salary of schooling levels has been on a steady increase since 2003 (see Table 2).

On the basis of the above findings, the expansion of higher education seems not to have led to negative effects on graduate employment. Graduate employment rate has been largely unchanged. Graduates seem to enjoy an increasing starting salary. However, we should note that the consumer price index has been rising. Yue (2012) introduced index of starting salary ${ }^{1}$ to probe into the implication of this increasing starting salary. The index has significantly declined from 1.35 in 2003 to 0.68 in 2011. The index of all levels of higher schooling has seen a significant decrease 
Table 3 Index of monthly starting salary of schooling levels

\begin{tabular}{lccccc}
\hline & 2003 & 2005 & 2007 & 2009 & 2011 \\
\hline 2-/3-year college & 1.16 & 0.93 & 0.68 & 0.56 & 0.53 \\
Bachelor & 1.29 & 1.07 & 0.87 & 0.85 & 0.78 \\
Master & 2.58 & 1.84 & 1.68 & 1.35 & 1.13 \\
Ph.D. & 2.60 & 2.00 & 1.58 & 1.40 & 1.45 \\
Total & 1.35 & 1.09 & 0.87 & 0.87 & 0.68 \\
\hline
\end{tabular}

Source: Yue $(2012,39)$.

Table 4 Job satisfaction (in percentage)

\begin{tabular}{lrrrrr}
\hline & 2003 & 2005 & 2007 & 2009 & 2011 \\
\hline Very satisfied & 6.3 & 4.6 & 12.0 & 16.4 & 11.1 \\
Satisfied & 38.4 & 32.8 & 41.1 & 43.1 & 43.6 \\
Fair & 46.4 & 50.0 & 40.0 & 34.3 & 40.0 \\
Unsatisfied & 7.3 & 10.3 & 6.0 & 5.5 & 4.7 \\
Very unsatisfied & 1.6 & 2.3 & 0.9 & 0.8 & 0.7 \\
\hline
\end{tabular}

Source: Yue $(2012,41)$.

(see Table 3). In this case, the expansion of higher education has failed to increase earnings, whereas graduates have not benefited much from the expansion policy.

Apart from the index of starting salary, we should also note job satisfaction, which is another aspect in evaluating the effect of the expansion of higher education on graduates in the labour market. Factors such as income, opportunity for upward occupational mobility, relationship among colleagues, control, and job characteristics closely influence the job satisfaction of graduates. Table 4 shows that the degree of such satisfaction has been steady, with a large number of graduates being satisfied with their job. Those who are unsatisfied with their job account for nearly $10 \%$ of the respondents.

Putting these findings together, we can observe that the expansion of higher education has had important effects on graduates in the labour market and social mobility. On the one hand, the expansion of higher education does not necessarily lead to upward social mobility. On the other, it has changed the role of higher education in the lives of the graduates in both social and economic regards to some extent. However, not all graduates face decreasing earnings in the intensifying globalization and expanding higher education systems.

\section{Global Competitiveness, Regional Education Hub, and Entrepreneurial University}

The paper contributed by William Lo sets out against the context of the globalization and highly competitive policy contexts in East Asia to examine the significance of the 
education hub in the future development of the higher education system in Hong Kong. This article begins by briefly examining the concept of education hubs and then looks into the major initiatives made by the Hong Kong government to promote its hub ambitions. As an international city in Asia, Hong Kong has made serious attempts to transform its higher education in the last decade to become a regional education hub. However, compared with its counterparts in Singapore and Malaysia, the Hong Kong government is less strategic and systematic in terms of policy measures in realizing the strategic goals. Hence, Hong Kong has lagged in the quest to become a regional education hub (Mok and Bodycott, 2014). Will Lo's article vividly highlights the tensions between Hong Kong and mainland China, particularly the special status of the higher education sector of Hong Kong in China under the 'one country, two systems' constitutional framework, and discusses whether the hub project can actually be realized. Examining the quest of Hong Kong for hub status in the light of the analytical framework by Knight and Lee (2014) for education hubs, the Hong Kong government has failed to develop a clear hub concept. By contrast, the government has attempted to utilize education services in general and the regional hub status in particular to diversify the economic pillars of Hong Kong by making education a new industry. Notwithstanding the call and attempts in asserting Hong Kong's education hub status, the government led by Chief Executive Leung Chun Ying has gradually downplayed the notion of a regional education hub since 2012 because the administration has selected another focus, providing sufficient social housing.

Against this context, the call for a regional education hub and the ambition to make education a new industry driving new economic growth has been dampened. Unsurprisingly, after reviewing the education hub project of Hong Kong, Mok and Bodycott (2014) commented as follows:

It has almost been a decade since the government has declared the aspiration of developing Hong Kong into an education hub, and yet the blueprint to do so has not been forthcoming. The goals and concrete strategies of the hub project have not yet been made clear and explicit. For The question of what kind of education hub is best for Hong Kong, the government has no answer yet. With many favourable conditions already in place, what is missing in Hong Kong's quest for the regional education hub status is the lack of political will. The government confines itself to the role of a facilitator only, as is evident in the launching of new funding and loan schemes, but it is reluctant to take up a more strategic leading role in steering and directing the development of the education hub project. (97)

Lo provides a good example of the difficulty in translating optimistic policy goals into policy implementation. We should consider education management issues as well as political and political economy perspectives when assessing the success and failure of a new education policy during implementation. 
Moving beyond Hong Kong, Jack Lee's contribution to this special issue compares and contrasts three regional education hubs, Malaysia, Singapore, and Hong Kong, to examine different roles of the governments in asserting their regional leadership through pushing the envelope of the regional education hub. Jack Lee clearly demonstrates the diverse definitions and understandings of regional education hubs, while his piece suggests the distinction between the role of a regional leader and regional broker when driving the hub projects. This comparative study shows how different policy objectives and strategies being adopted by the governments of Singapore, Malaysia, and Hong Kong when implementing the regional hub projects, inevitably led to different results and achievements of policy objectives. Jack Lee's article shows the impact of the 'visible hands' of the state in the case of Singapore and Malaysia. Particularly in Malaysia, the government has played an important role as broker in the regional hub project. Singapore and Hong Kong have made use of the regional education hub status not primarily aiming at revenue seeking but on a strategy of soft power and regional leadership. Capitalizing on their assets with respect to their unique geographical locations, these Asian states have made serious attempts to enhance their global competitiveness by active regional engagement.

In responding to the changing needs of social and economic development, universities have been encouraged to be more responsive or innovative for the past two decades. Clark $(1998,2004)$ examined how the behaviour of universities has changed against the context of being driven to become more entrepreneurial and enterprising. Sporn (1999) asserted that if universities can be more entrepreneurial, then institutions are more likely to meet new social and economic demands via innovative measures. Institutions and individuals alike require entrepreneurship. In other words, possessing skills or capacity of being entrepreneurial and innovative can create more employment opportunities and even promote engagement in the advancement of local communities. Against such a context, a growing number of governments in Asia have also become keen to promote the concept of the entrepreneurial university to bring greater advantages to society as a whole (Wong, 2011). Critically examining how universities and governments in East Asia have responded to growing pressure to become more globally competitive by engaging in different forms of entrepreneurial activities and innovation promotion, Mok (2013a) conducted a comparative study on policies and strategies adopted by governments and universities in East Asia to promote innovation and knowledge transfer activities by encouraging university-enterprise cooperation.

As part of the larger comparative project, Mok's article in this special issue critically reviews the policies and reform measures that the Singapore government has adopted in the last two decades. These efforts aim to transform its university sector and drive them to engage in the promotion of innovation, entrepreneurship, and technical advancement by partnering with industry and business. After reviewing the policy backgrounds on how universities have responded to the new national agenda for economic development by promoting innovation and entrepreneurship, 
Mok emphasizes the major projects conducted by universities in Singapore to engage with the industry and business in promoting innovation and knowledge transfer activities. Mok surveyed and interviewed academics in Singapore to examine how they evaluate and assess the growing pressures for fostering university-enterprise cooperation, and found diverse responses. Academics in business and engineering sectors were more sympathetic to university-enterprise cooperation, whereas those in humanities and social sciences have difficulty engaging in deep cooperation with business and industry. Similar to the findings generated from other East Asian societies, such as Taiwan, South Korea, and Hong Kong, academics in humanities and social sciences find difficulty in the continuous emphasis on the importance of university-enterprise cooperation by university authorities that are not sufficiently sensitive towards the diversity of academic disciplines. Academics are particularly worried about the possible institutionalization of performance assessment in terms of knowledge transfer gearing towards the standardization of science, business, and engineering without paying special attention to the differences of humanities and social sciences. Chan and Mok (2014) believe that standardization in measuring university outputs and performance will inevitably cause anxiety among academics, particularly that academic freedom and autonomy are jeopardized.

In terms of academic freedom, heated debates have focused on the extent of academic freedom or academic autonomy in universities, as well as the importance of such concepts to the success of contemporary universities. Marginson (2014) conducted a global comparative study on academic freedom and argues the following:

Academic freedom is best understood not as an abstract universal principle or an ideal state of being but as concrete university practices nested in specific relational environments. As such, practices of academic freedom vary across the world, according to variations in political cultures, educational cultures and state-university relations. (24)

When we discuss how the growing trend of university-enterprise cooperation and the drive for enterprising university has affected university governance, we must pay particular attention to the issues related to academic freedom and autonomy against the growing pressure for universities to show their impacts on social and economic developments. Aligning universities and higher education systems with the challenges of emergent knowledge economies has become an increasingly important policy discourse in East Asia, especially when governments in the region have begun finding a way to justify spending more public money on higher education. People have begun asking for cost-benefit analyses in a call for accountability (James, 2012).

When measuring how universities have performed in the recent past, we have witnessed the growing popularity of different kinds of global university leagues. Chow and Loo - in this special issue - analyse how global cities perform in terms 
of the universities they host and bring a geographical perspective in assessing global city performance through higher education. They argue that the global geography of higher education is a black box, although the internationalization of education studies is abundant. Little is known about the distribution of higher education activities among cities despite common transnational interactions under globalization. Their paper measures the performance of a city in relevant activities and addresses the importance, challenges, and potential of studying higher education from geographical perspectives, especially at an inter-city scale. Chow and Loo analyse the formulation of the Globalizing Education Index that consists of place power and network power and reveal that decentralization and centralization occur simultaneously. This finding added additional insight to the existing literature, showing a decreasing central-periphery landscape of scholarly activities in the global education system. Given that the knowledge economy and the global commercial economy resemble each other, the comparison of cities' performance in selected East Asian economies introduces the need to diversify existing methodologies in examining global city rankings.

\section{Conclusion: Implications for Education Equality and Impact on Academic Profession}

The above discussions and analysis show that the massive expansion of higher education has not promoted equality in education but further intensified education inequality in Asia, particularly in China. This resonates with the study of Neubauer and Hawkins (2014), who argued the following:

The majority of the enrollment growth in coming years will be in two countries, China and India, both of which have massive populations, but both of which also are characterized by very significant patterns of income and social inequality, a characteristic both within urban populations but especially existing between urban and rural populations. (3)

Similarly, Mok's critical review (2014) on how privatization has affected families showed that those with children and from lower socioeconomic status in Hong Kong have suffered most from the privatization of education. On the basis of the census data in Hong Kong, Chou (2013) found that young adults from middle- or upperclass families enjoy far more higher education opportunities (nearly threefold) than those from relatively low-income groups.

The number of children in a household also has a significant bearing on poverty risk. Specifically, the more the number of children in a household, the higher the poverty risk. The burden of childcare may constrain the ability of household members to exploit employment opportunities. Thus, ways to design measures that target low-income households with children must be considered in formulating 
new poverty-relief initiatives. Such students are not sufficiently prepared for higher education. Findings have suggested that even if the diversity of students in higher education increases, this will increase the propensity of dropping out. An additional projected effect is students attending low quality and sometimes exploitative higher education institutions, which are created to 'serve' these underprepared populations and whose continued existence is often rationalized by their ability to maintain 'head counts' irrespective of educational quality (Bettinger and Bridget, 2009). Green and Mok (2013) compared the massification of higher education in Europe and Asia, which indicates an emerging crisis of the youth, that is, higher investment from parents in higher education by paying high fees but less secure job opportunities for their children after graduation. Brown et al. (2011) argued that university graduates are confronted with an 'opportunity trap' in which they face the 'global auction'; high-skill jobs are paid with low salaries because the global labour market can easily offer an abundant supply of highly qualified and skilled labourers who compete for a small number of positions. Brown et al. $(2011,132)$ stated, 'extending opportunities based on human capital investment will not deliver individual freedom or prosperity but rather contribute to an opportunity trap'. Moreover, 'the trap points to increasing social congestion for decent jobs as people scramble for highly rates schools, colleges and jobs' (Brown et al., 2011, 135). In this case, not all university graduates can secure a good job. If such graduates desire better work, they must first obtain a higher education degree.

Putting these developments into perspective, the massification and privatization of higher education have resulted in highly complicated graduate employment and social mobility problems currently confronted by the youth. Therefore, student movements in Europe and Asia in which anxieties and anger are expressed against the ruling regimes are unsurprisingly widespread. All the issues discussed above have inevitably affected the academic profession. The rapid expansion of higher education in Asia implies that teaching and research are carried out by staff who are less qualified, overworked with heavy teaching load, have to teach large classes, are paid low salaries, and are given little opportunity to provide personal attention to students. Neubauer and Hawkins $(2014,4)$ observed that 'in many of these contemporary massified higher education systems in the Asia Pacific region, faculty at "lesser regarded" institutions are often forced to hold positions at multiple institutions, a situation that leads to a downward cascade of professional preparation, timeliness of knowledge, as well as energy to teach effectively'. This situation may be seen to approximate a 'beggaring' of this fraction of the academic profession, as Chapman (2009) argued.

Academics commonly experience intensified pressures when performance is not only related to research and teaching but also when knowledge transfer and income generation from their engagements with industry and business are emphasized (Mok, 2013a; Chan and Mok, 2014). In conclusion, the papers in this special issue highlight the most significant challenges that universities face in Asia, as well as those experienced by academics during rapid transformations in higher education. 
Asia should be congratulated for its efforts to improve standards in higher education, but we should not drive reforms to make changes without placing equally important emphasis on universities achieving excellence holistically (Mok and Nelson, 2013). Bringing back the humanistic perspective in university governance and transformation is urgently needed. Academics and administrators in Asian higher education systems should shift attention towards the quest for excellence not only for efficiency and economic gains but also for human wellbeing enhancement.

\section{Acknowledgements}

The author wants to thank the Research Grant Council of the HKSAR government for providing funding support to conduct the fieldwork and survey in different East Asian countries. Part of the findings reported in the present paper (particularly the discussion on university-enterprise cooperation and academic reflections) is generated from the funded project HKIEd GRF 750210 'Fostering Entrepreneurship and Innovation: A Comparative Study of Changing Roles of Universities in East Asia'.

\section{Note}

1 Starting salary index is defined as a measure of yearly starting salaries of graduates for the average monthly salary of urban employees.

\section{References}

Bettinger, E.P. and Bridget, T.L. (2009) 'Addressing the needs of under-prepared students in higher education: does college remediation work?' Journal of Human Resources 44(3): 736-771.

Brown, P., Lauder, H. and Ashton, D. (2011) The Global Auction: The Broken Promises of Education, Jobs, and Incomes, New York: Oxford University Press.

Calderon, A. (2012) 'Massification continues to transform higher education', University World News, 2 September, http://www.universityworldnews.com/article.php?story $=20120831155341147$, accessed 7 June 2014.

Carnoy, M., Loyalka, P., Dobryakova, M., Dossani, R., Froumin, I., Kuhns, K., Tilak, J.B.G. and Wang, R. (2013) University Expansion in a Changing Global Economy: Triumph of the BRICs? Stanford, CA: Stanford University Press.

Chan, S.J. and Mok, K.H. (2014) 'The Quest for the Entrepreneurial University in Taiwan: Policies, Practices and Academic Reflections on University-Enterprise Cooperation', in J. Hawkins and K.H. Mok (eds.) Research, Development and Innovation in Asia Pacific Higher Education, New York: Palgrave Macmillan.

Chapman, D.W. (2009) Higher Education in East Asia, Washington DC: World Bank.

Chou, K.L. (2013) 'Education inequality in higher education in Hong Kong', Press Conference of the Study on Education Opportunity and Social Classes in Hong Kong, March, Hong Kong Institute of Education.

Clark, B. (1998) Creating Entrepreneurial Universities: Organizational Pathways of Transformation, Bingley, UK: Emerald Group Publishing Limited. 
Clark, B. (2004) Sustaining Change in Universities: Continuities in Case Studies and Concepts, Maidenhead, UK: Open University Press.

Coleman, J.S., Campbell, E.Q., Hobson, C.J., McPartland, J., Mood, A.M., Weinfeld, F.D. and York, R.C. (1966) Equality of Educational Opportunity, 3rd edn, New Hampshire: Salem.

Green, A. and Mok, K.H. (2013) 'Expansion of higher education, changing labor market needs and social mobility: A dialogue between Europe and East Asia'. Paper presented at the 2013 Annual Conference of The Hong Kong Educational Research Association Managing International Connectivity and Diversity: Experiences of Asian World Cities, 22 February, Hong Kong.

Haveman, R.H. and Smeeding, T.M. (2006) 'The role of higher education in social mobility', The Future of children 16(2): 125-150.

James, R. (2012) 'Aligning Universities and Higher Education Systems with the Challenges of Emergent Knowledge Economies', in D. Neubauer (ed.) The Emergent Knowledge Society and the Future of Higher Education, London: Routledge, pp. 41-54.

Knight, J. and Lee, J. (2014) 'An Analytical Framework for Education Hubs', in J. Knight (ed.) International Education Hubs: Student, Talent, Knowledge-Innovation Models, Dordrecht: Springer, pp. $29-42$.

Ku, Y.W. (2014) 'Democracy without governance: Policy failure in Taiwan'. Paper presented at the Inaugural Conference of NYU-ECNU Institute for Social Development at New York University Shanghai Campus, 28-29 June, Shanghai, China.

Marginson, S. (2014) 'Academic freedom: a global comparative approach', Frontiers of Education in China 9(1): 24-41.

Mok, K.H. (2012) 'The quest for innovation and entrepreneurship: the changing role of university in East Asia', Globalization, Education and Society 10(3): 317-336.

Mok, K.H. (2013a) The Quest for Entrepreneurial Universities in East Asia, New York: Palgrave Macmillan.

Mok, K.H. (2013b) 'The quest for an entrepreneurial university in East Asia: impact on academics and administrators in higher education', Asia Pacific Education Review 14(1): 11-22.

Mok, K.H. and Bodycott, P. (2014) 'Hong Kong: The Quest for Regional Education Hub Status', in J. Knight (ed.) International Education Hubs - Student, Talent, Knowledge-Innovations Models, Dordrecht: Springer, pp. 81-99.

Mok, K.H. and Nelson, A. (2013) 'The changing roles of academics and administrators in times of uncertainty', Asia Pacific Education Review 14(1): 1-9.

Mok, K.H., Yu, K.M. and Ku, Y.W. (2013) 'After massification of higher education: the quest for entrepreneurial university and technological advancement in Taiwan', Journal of Higher Education Policy and Management 35(3): 264-279.

Neubauer, D. and Hawkins, J. (2014) 'The many faces of Asia Pacific higher education in the era of massification'. Paper presented at the Senior Seminar on The Many Faces of Asia Pacific Higher Education in the Era of Massification, 17-19 October, Hong Kong.

Shaw, M.A., Chapman, D.W. and Rumyantseva, N.L. (2011) 'Caught in a double bind: The impacts of the Bologna process on academic staff in Ukraine', Higher Education Management and Policy 23(3): 71-91.

Sporn, B. (1999) Adaptive University Structures: An analysis of Adaptation of Socioeconomic Environments of US and European Universities, London and Philadelphia: Jessica Kingsley Publishers.

Turner, A. and Yolcu, H. (eds.) (2014) Neo-liberal Educational Reforms: A Critical Analysis, London: Routledge.

Wang, L. and Mok, K.H. (2014) 'The Impacts of Neo-Liberalism on Higher Education in China', in A. Turner and H. Yolcu (eds.) Neo-liberal Educational Reforms: A Critical Analysis, London: Routledge, pp. 139-163. 
Wen, D. (2005) “jiating beijing dui wo guo daodeng jiaoyu jihui ji biye sheng jiuye de yingxiang' (The impacts of SES on higher education opportunity and graduate employment in China)', beijing daxue jiaoyu pinglun (Peking University Education Review) 3(3): 58-63.

Wolverton, M. (2014) 'Creating Creative Creators: China and the United State's Common Quest', in Q. Li and C. Gerstl-Pepin (eds.) Survival of the Fittest: The Shifting Contours of Higher Education in China and the United States, Dordrecht: Springer, pp. 3-12.

Wong, P.K. (ed.) (2011) Academic Entrepreneurship in Asia: The Role and Impact of Universities in National Innovation Systems, Cheltenham, UK: Edward Elgar Publishing.

Yue, C.J. (2012) "gao xiao bi ye sheng jiu ye zhuang kuang fen xi: 2003-2011' (A comparative study on graduates employment survey: 2003-2011)', Peking University Education Review 10(1): 32-47.

Zha, Q. and Lin, J. (2014) 'China's Move to Mass Higher Education: Analyzing the Policy Execution with a 'NATO-Scheme", in Q. Li and C. Gerstl-Pepin (eds.) Survival of the Fittest: The Shifting Contours of Higher Education in China and the United States, Dordrecht: Springer, pp. 29-40. 